\title{
Ministerial Influence at the Canadian Immigration and Refugee Board: The Case for Institutional Bias
}

\author{
JACQUELINE BONISTEEL
}

\begin{abstract}
This paper explores the implications of Canada's Immigration Minister Jason Kenney's July 2009 comments on Mexican and Czech refugee claimants that accompanied the imposition of visas for these two countries. I argue that the Minister's comments, in concert with his control over the tenure of Immigration and Refugee Board members, substantiate a claim that the Board is institutionally biased. While allegations of institutional bias have not fared particularly well in Canadian courts, I contend that the applicability of section 7 Charter rights distinguishes the immigration and refugee context, and makes success more probable. Specifically, I posit that the Minister's comments have opened a window of opportunity to bring an end to the executive's unfettered discretion over IRB reappointments, since the most effective remedy to address institutional bias would be amendment of the reappointment process.
\end{abstract}

\section{Résumé}

Cet article étudie les incidences de commentaires faits par le ministre canadien de l'Immigration, Jason Kenney, en juillet 2009 au sujet des demandeurs d'asile mexicains et tchèques entourant l'imposition du visa pour ces deux pays. L'auteur soutient que les commentaires du ministre, de concert avec son contrôle sur la durée des mandats des membres de la Commission de l'immigration et du statut de réfugié, étayent une allégation de partialité institutionnelle contre la Commission. Malgré l'insuccès de telles démarches devant les tribunaux canadiens, l'auteur soutient que l'applicabilité de l'article 7 de la Charte distingue le contexte de l'immigration et des réfugiés et rend le succès plus probable. Plus précisément, l'auteur propose que les commentaires du ministre ont ouvert une "fenêtre d'opportunité " pour mettre un terme à la libre discrétion de l'exécutif sur le renouvellement des mandats des membres de la CISR, puisque le remède le plus efficace pour traiter la partialité institutionnelle serait une modification du processus de renouvellement.

\section{Introduction}

On July 13, 2009, Canada's Minister of Citizenship, Immigration and Multiculturalism, Jason Kenney, announced that Canada would be imposing visas on citizens from Mexico and the Czech Republic. The aim was to stem the tide of refugee claimants from what were respectively the number one and number two source countries for claims made in Canada. In a press release, Minister Kenney explained that the delay and costs associated with processing this high claim volume was "undermining our ability to help people fleeing real persecution." ${ }^{1}$ His implication was clear: most Mexican and Czech claimants were not genuine refugees.

The Minister's comments to various media outlets over the following days confirmed his outlook. He argued that "the vast majority of Mexico's refugee claimants are economic migrants from the middle class,"2 and that "[i]t's an insult to the important concept of refugee protection to allow it be systematically violated by people who are overwhelmingly economic migrants."3 Regarding Czech Roma, who represent the vast majority of claimants from the Czech Republic, Minister Kenney argued that they are free to move elsewhere in Europe and therefore are not real refugees. ${ }^{4} \mathrm{He}$ also referenced an Immigration and Refugee 
Board (IRB) fact-finding report which found no evidence of state-sponsored persecution of Czech Roma, stating, "[i]f someone comes in and says the police have been beating the crap out of them, the IRB panelist can then go to their report and say, 'Well, actually, there's been no evidence of police brutality." 5

These statements were met with condemnation from both academic and advocacy circles. While some focused upon the lack of supporting evidence for the Minister's claims, ${ }^{6}$ the predominant concern was a perceived encroachment upon IRB legislative authority. The Canadian Council for Refugees and the Refugee Lawyers' Association of Ontario agreed that the comments constituted political interference with the independence of the IRB, which retains sole authority to decide individual refugee claims. ${ }^{7}$ Former IRB chairperson Peter Showler said, "I think [the Minister] has overstepped the line, and I think the courts are going to tell him that he's overstepped the line."8 Rocco Galati, a Toronto immigration lawyer, announced plans to bring a lawsuit on behalf of Czech Roma refugees, based on alleged IRB institutional bias. ${ }^{9}$

This paper will explore the feasibility of such a lawsuit and suggest a litigation strategy for presenting an argument that the IRB is institutionally biased. I contend that the Minister's comments following the visa impositions, in concert with his control over the tenure of IRB members, substantiate a claim of institutional bias. While such arguments have not fared particularly well in Canadian courts, I will argue that the applicability of rights under section 7 of the Canadian Charter of Rights and Freedoms distinguishes the immigration and refugee context and makes success more probable. Specifically, I posit that the Minister's comments have opened a window of opportunity to bring an end to the executive's unfettered discretion over IRB reappointments, since the most effective remedy to address institutional bias would be amendment of the reappointment process.

\section{High Degree of Independence Required in the Refugee Determination Context}

The Immigration and Refugee Protection Act (IRPA) provides all divisions of the IRB with "sole and exclusive jurisdiction to hear and determine all questions of law and fact, including questions of jurisdiction." 10 This language conveys a legislative intent to bestow on the Board full and unqualified decision-making authority. The existence of this intent is further substantiated by the IRPA's objectives, which include the granting of "fair consideration to those who come to Canada claiming persecution," 11 and the establishment of "fair and efficient procedures that will maintain the integrity of the Canadian refugee protection system, while upholding Canada's respect for the human rights and fundamental freedoms of all human beings." 12 Impartial decision making is central to maintaining a fair process that accounts for the unique situation of each claimant.

While the Supreme Court of Canada (SCC) held in Ocean Port Hotel Ltd. v British Columbia (Liquor Control and Licensing Branch, General Manager) that administrative tribunals, as a general rule, are not held to the level of independence required of the judiciary under section 11(d) of the Charter, McLachlin CJ acknowledged that exceptions may exist where Charter rights are implicated. ${ }^{13}$ In the refugee determination context, it has been accepted that IRB decision makers have the potential to exercise power over claimants' section 7 rights to life, liberty, and security of the person. Wilson J's decision in Singh can be cited for the proposition that section 7 is engaged in the refugee determination process. ${ }^{14}$ While Wilson J's reasons were endorsed by only Dickson CJ and Lamer J, the other three participating justices made no contrary conclusions on the applicability of section 7.15 Subsequent courts applying Singh have accepted that section 7 is engaged in the refugee determination process. ${ }^{16}$ It is also notable that a unanimous SCC later ruled in Suresh that " $[\mathrm{t}]$ he greater the effect on the life of the individual by the decision, the greater the need for procedural protections to meet the common law duty of fairness and the requirements of fundamental justice under s. 7 of the Charter." 17 In that case, the Court concluded that deportation of a refugee to face a substantial risk of torture would generally violate section $7 .^{18}$

Thus, given that section 7 of the Charter is engaged in the refugee determination context, a more stringent standard of decision-maker independence is warranted. As Gerald Heckman and Lorne Sossin put it, "[s]urely if a party has the right to claim the protection of the Charter, they have a corresponding right to an independent and impartial resolution of that claim." 19 The Federal Court of Appeal endorsed this conclusion in the 2006 Kozak case. Evans CJ stated that " $[\mathrm{t}]$ he independence of the [IRB], its adjudicative procedure and functions, and the fact that its decisions affect the Charter rights of claimants, indicate that the content of the duty of fairness owed by the Board, including the duty of impartiality, falls at the high end of the continuum of procedural fairness." 20 The IRB is therefore among those exceptional tribunals for which rigorous procedural fairness, including the right to an independent and impartial decision maker, appears to be required.

Valente established three indicia of judicial independence: security of tenure, security of remuneration, and administrative control. ${ }^{21}$ These principles were found to be applicable to administrative tribunals in Canadian Pacific Ltd. $v$ Matsqui Indian Band, but Lamer CJ noted that the requisite level of independence is more flexible in the administrative context, and depends upon "the nature of the tribunal, the 
interests at stake, and other indices of independence such as oaths of office." ${ }^{22}$ As established above, IRB members are to be afforded a high degree of independence. Thus, each of the three indicia ought to be assured. Security of remuneration and administrative control are not controversial in this context: security of tenure is the factor at issue.

\section{Insufficient Security of Tenure at the IRB: The Reappointments Process}

IRB members are Governor-in-Council (GIC) appointees who, within any given term, may only be removed for cause. ${ }^{23}$ The IRPA provides for good behaviour terms of up to seven years but, following the 2007 recommendation of the Public Appointments Commission Secretariat, initial terms have consistently been set at three years. ${ }^{24}$ Regarding reappointment, the IRPA states that members "are eligible for reappointment in the same or another capacity." 25 The legislation offers no further guidelines on how the reappointments process is to be carried out.

The IRB appointment and reappointment process has been a subject of controversy for some time. In December 1997, the Auditor General expressed concern with member recruitment methods, candidate evaluation, and reappointment recommendations. ${ }^{26}$ The appointments process was eventually amended-first in 2004, and again in July 2007-to incorporate these and other expert recommendations. The changes included measures to increase transparency and fairness and to ensure that appointments were merit-based. ${ }^{27}$

Though these improvements to appointment practices are laudable, changes to the reappointments process have not been on an equivalent scale. In 1997, Board members told the Auditor General that exemplary performance provided no guarantee of reappointment. ${ }^{28}$ In response, a new performance appraisal system was implemented in 1999. Responsibility for recommending renewals was transferred from a Ministerial Advisory Committee to an internal IRB Performance Review Committee. ${ }^{29}$ The Committee was charged with overseeing the appraisal process and providing a report to the Minister "at the end of a member's term as advice on reappointment." 30 The Minister is not obligated to take the recommendation into account, but the IRB website states that the reappointment process "will continue to reflect a performance evaluation consistent with the meritbased competency criteria." 31

In March 2009, the Auditor General report revealed that, while the performance review evaluation process was being carried out well, its impact was less pronounced than expected. A review that took place between 1 January 2006 and 31 March 2008 found that, of the eighty-nine members who were recommended to the Minister by the
Performance Review Committee, the Governor-in-Council reappointed thirty-seven (42 per cent). In roughly the same period (September 2006 to March 2008), forty-three new appointments were made. ${ }^{32}$ These numbers are surprising, given the Board's estimate that it takes between six and twelve months and $\$ 100,000$ to fully train a new member. ${ }^{33}$ If an existing member's performance review is positive, why would the Minister choose to bear the expense of hiring and training a new member, rather than recommending reappointment? An explanation is not available, but it may be reasonable to infer that the performance review is not a determinative factor in reappointment decision making.

Concern surrounding the failure to reappoint qualified and competent members was conveyed by a representative of the Canadian Council for Refugees in a May 2007 report of the House of Commons Standing Committee on Citizenship and Immigration. ${ }^{34}$ In that same report, JeanGuy Fleury, the IRB chairperson at the time, and Nick Summers, a former member of the IRB advisory panel, both suggested that the Minister's discretion over reappointments created a politicized process. Mr. Fleury was of the opinion that the process ought to be amended to allow the chairperson to control reappointments. ${ }^{35}$

Valente established that the basic requirement for security of tenure for the purposes of section $11(d)$ is "a tenure, whether until an age of retirement, for a fixed term, or for a specific adjudicative task, that is secure against interference by the Executive or other appointing authority in a discretionary or arbitrary manner." 36 The SCC has not ruled clearly on the meaning of security of tenure in the administrative context, ${ }^{37}$ but existing case law suggests that the requirements are relatively lenient. In 2747-3174 Québec Inc. $v$ Québec (Régie des permis d'alcool), a fixed-term appointment of up to five years, with reappointment decisions informed by a performance evaluation, was found to be acceptable for a liquor licensing body to which the Quebec Charter of Human Rights and Freedoms applied. ${ }^{38}$ In Bell Canada $v$ Canadian Telephone Employees Association, the chairperson's discretionary power to extend appointments to the Canadian Human Rights Commission was not deemed to compromise independence. ${ }^{39}$

Given that IRB members enjoy fixed terms of similar duration to those in Régie, with dismissal only for cause and discretionary reappointments, it would appear that the case law contradicts an argument that security of tenure at the IRB is inadequate. However, in both Régie and Bell, section 7 Charter rights were not implicated. Régie, it should be acknowledged, did concern the right to a public and fair hearing before an independent and impartial tribunal under section 23 of Quebec's Charter of Human Rights and Freedoms. ${ }^{40}$ However, the refugee determination 
context can be distinguished from that of liquor licensing. While the right of a permit holder to operate a business is an important economic right, refugee claimants face potential deportation to situations where their life, liberty, and security of the person will be denied. An argument can be made that, given these circumstances, the independence requirements for the IRB ought to be among the most stringent for administrative tribunals, and closer to the standard required of courts, where an unwritten constitutional principle of judicial independence applies. ${ }^{41}$

While Valente does not specify the length of a "fixed term" that would be sufficient in the judicial context, it would certainly be more than three years. The standard would likely be much closer to that specified for section 96 courts, which is the age of retirement. Of course, holding an administrative tribunal to the same standard as a court would be unreasonable given that tribunals play a different societal function. However, for a tribunal with a court-like character and the potential to impinge upon section 7 Charter rights, the standard arguably ought to be higher than a three-year term with entirely discretionary possibility of reappointment. This context is also distinguished by the fact that IRB members are generally reappointed for seven-year terms. ${ }^{42}$ As the renewal term is substantially longer than the initial appointment, there is a strong incentive for members to do whatever they perceive to be necessary to secure reappointment.

\section{Institutional Bias}

The test for institutional bias, introduced in $R v$ Lippé, asks whether a well-informed person would have a reasonable apprehension of bias in a substantial number of cases. ${ }^{43}$ To be valid, an apprehension of bias must be "a reasonable one, held by reasonable and right-minded persons, applying themselves to the question and obtaining thereon the required information." 44 In the context of administrative tribunals, a more flexible test is usually acceptable. ${ }^{45}$ However, as detailed above, a lesser degree of flexibility is warranted in this context, given the IRB's quasi-judicial character and impact on Charter rights.

The argument that ministerial discretion over reappointments encroaches upon security of tenure may be sufficient on its own to ground a case for IRB institutional bias. However, the case is strengthened significantly by Minister Kenney's recent media comments. These comments, combined with ministerial discretion over the reappointments process, lead to a reasonable apprehension of bias in all refugee determination proceedings for claimants from Mexico and the Czech Republic. The logic is straightforward: the Minister has publicly displayed a glaring negative bias towards claimants from these two countries. Board members, who rely on this same Minister to be reappointed to their position, may very well be predisposed to reject Mexican and Czech claimants in order to secure ministerial favour and avoid potential reprisal in the form of nonreappointment. In the words of University of Toronto law professor Audrey Macklin, "[t]hey might be fearful when their time comes up for reappointment that he will examine their acceptance rates from the countries where he has deemed refugee claimants to be bogus, and penalize them." 46 Macklin's contention is valid: the Minister does, in fact, have access to data on how each individual Board member decides on claims originating from specific countries. The name of the presiding Board member is included in the reasons of each Refugee Protection Division decision, and these reasons are publicly available online.

Whether individual IRB members are in fact biased is irrelevant to the determination of a potential lawsuit. Sara Blake points out that a minister's bias does not necessarily imply that an adjudicator employed by his or her ministry is biased. ${ }^{47} \mathrm{~A}$ decision to reject a Mexican or Czech claim could still be made based on impartial reasoning with regard to the individual circumstances and a well-reasoned evaluation of the wider context, with no consideration of the Minister's views. In fact, the Minister's statements may merely have been unprofessional, but not legally problematic, if IRB members were more insulated from ministerial influence. It is the combination of the comments, the discretionary reappointment process, and the significance of the rights affected that substantiates a legal challenge. The appearance of fairness is as essential to maintaining the integrity of the refugee determination process as actual lack of prejudice. Thus, if a reasonable apprehension of bias can be established based on the Minister's comments and his control over reappointments, all decisions concerning Mexican and Czech claims will be invalid, regardless of their individual quality.

In Sethi v Canada, the Federal Court of Appeal held that members of the antecedent refugee determination body who faced potential appointment to the new IRB could not have felt pressure to render negative decisions, as the government had no interest in seeing refugee claims defeated. ${ }^{48}$ However, Judith McCormack writes that the judgment displayed "a certain myopia" 49 and, as we now have persuasive evidence that Minister Kenney did, in fact, have an interest in stemming the tide of Mexican and Czech refugees, there is a strong possibility that a court would decide differently at present.

International norms and jurisprudence can be applied to bolster the institutional bias argument. The European Court of Human Rights, for instance, has placed more emphasis than Canadian courts on "guarantees against outside pressure" and 
the appearance of independence. ${ }^{50}$ Institutional bias has also been argued along a similar line in the context of Australia's Refugee Review Tribunal. ${ }^{51}$ If the lack of Canadian precedent poses any hurdles, international jurisprudence provides additional justification for judicial scrutiny of the Minister's interference with Board decision making.

\section{Bringing the Challenge to Court}

As mentioned above, the case for IRB institutional bias does not hang upon Minister Kenney's comments-the inadequacy of the discretionary reappointments process is sufficient on its own. However, Minister Kenney's comments add significant weight to an attempt to have the process amended. The best way to bring the challenge would be in the context of one or several refugee claim(s) from a country about which the Minister has made biased comments. Unfortunately, this may prove difficult in the context of Mexican and Czech claims given that almost two years have now passed since the comments were made and, if institutional bias is not raised from the outset of proceedings, parties are not normally able to complain. ${ }^{52}$ Furthermore, the visa imposition has brought Mexican and Czech claims to a near halt. Still, the Minister has not revoked or qualified his comments, so they can still be cited as an accurate expression of his views. Thus, at this stage, an argument for institutional bias based in part upon these comments could still be raised for Mexican and Czech cases at a preliminary stage. Additionally, it may be possible to bring a similar challenge based on the Minister's more recent comments implying that asylum seekers who have arrived in Canada via human smugglers are queue jumpers "taking up space and resources in our immigration and refugee systems that should be focused on those who are legitimately and lawfully waiting their turn to come to Canada." 53

Institutional bias arguments were raised in a series of 2010 Federal Court cases involving Czech refugee claimants. ${ }^{54}$ In each of these cases, the Court rejected the applicant's contention that Minister Kenney's comments led to a reasonable apprehension of bias against Czech claimants. However, the arguments in these cases were presented in an incomplete manner. In Gabor, Zinn J refused to attach much weight to the media comments by Peter Showler, Audrey Macklin, and others because they were not presented in the form of sworn affidavits and were speculative and unsupported. ${ }^{55}$ In Cervenakova, the applicant merely stated that the reappointments process contributes to a reasonable apprehension of bias, and did not adduce evidence of "attenuated independence on the part of the Board or any of its members." 56 In Zupko, Snider J stated, "I have no evidence, beyond bare speculation, that appointments are made on the basis of prospective members' views of the
Minister's speeches or that the renewal of Board member appointments is made on the basis of, or influenced by, their refugee claim acceptance rates." 57 Thus, in each of these cases, the institutional bias argument does not appear to have been presented fully and coherently, and the evidentiary basis for key assertions was lacking. A more carefully formed argument may well fare better.

A court finding institutional bias would likely set aside a Board decision to which the bias applied and call for it to be reheard before a properly constituted panel. Forming a properly constituted panel would require legislative changes to the reappointment process, which would take time, and could cause nightmarish delays to an already overburdened and backlogged refugee determination system. This concern is not insignificant-increased delays would have significant consequences for claimants and taxpayers alike. However, this difficulty must be balanced against Canada's need for a fair and unbiased refugee determination system that meets our human rights obligations at the national and international levels. Furthermore, the required changes would be relatively simple. The IRB already has a highquality performance evaluation process in place. A sound policy would simply require that the Minister adopt the Performance Review Committee recommendations in the absence of clear and valid reasons to do otherwise. The potentially serious impact of delays would provide an incentive to the legislature to act quickly, thus ensuring that the delay would be minimally disruptive.

A brief comment on Bill C-11, the Balanced Refugee Reform Act, is warranted at this stage. The Bill has received royal assent, and its reforms are due to come into effect in late 2011. The appointment and reappointment processes for the new Refugee Appeal Division (RAD) are to remain unchanged from the current system applicable to IRB members. As such, it would appear that the argument made in this paper will remain applicable in that the RAD reappointments process will raise the same institutional bias concerns.

\section{Conclusion}

Minister Kenney's comments on Mexican and Czech refugee claimants overstepped his legislative authority and highlighted the Minister's current power to compromise independent decision making at the IRB. This situation is worrisome given the immense importance of having a fair and balanced refugee determination process in place in Canada. I submit that the case for institutional bias is strong and that amendment of the IRB reappointments process is the proper way to remedy this issue and maintain the integrity of our system. While Canadian courts have not been overly receptive to institutional bias arguments in other 
contexts, the applicability of section 7 Charter rights in the refugee determination context makes the argument more persuasive. The time is ripe for bringing a legal challenge on this basis.

\section{Notes}

1. Citizenship and Immigration Canada, News Release, "Canada Imposes a Visa on the Czech Republic" (13 July 2009) online: http://www.cic.gc.ca/English/department/media/ releases/2009/2009-07-13a.asp; Citizenship and Immigration Canada, News Release, "Canada Imposes a Visa on Mexico" (13 July 2009) online: http://www.cic.gc.ca/ EnGLIsh/department/media/releases/2009/2009-07-13 .asp.

2. Mike Blanchfield, "Not worried over Czech, Mexican visa fallout: Kenney", The National Post (14 July 2009) online: The National Post http://www.nationalpost.com/news/ story.html?id=1789233.

3. "Canada defends visa change for Mexicans, Czechs", $C B C$ News (14 July 2009) online: CBC News http://www.cbc.ca/ world/story/2009/07/14/czech-visas-mexico.html.

4. "Kenney Defends Visa Rules of Czech Nationals", CTV News (14 July 2009) online: CTV News http://ottawa.ctv.ca/ servlet/an/plocal/CTVNews/20090714/visas_immigration _090714/20090714/?hub=OttawaHome.

5. Lesley Ciarula Taylor, "Refugee advocates criticize minister", Toronto Star (4 July 2009) online: Toronto Star http:// www.thestar.com/news/canada/article/660846.

6. ReuelS.Amdur,"ThePlight of the Roma:FromEuropetoCanada" Toward Freedom (11 November 2009), online: Toward Freedom http://towardfreedom.com/home/content/view /1748/1/; Peter Showler, “The Bogus Refugee Myth”, Editorial, The Ottawa Citizen (12 August 2009) online: The Ottawa Citizen http://www.ottawacitizen.com/story_print. html?id=1886018\&sponsor $=$.

7. Canadian Council for Refugees, Media Release, "Visas on Mexico and Czech Republic close the door on refugees" (14 July 2009) online: CCR http://www.ccrweb.ca/ en/bulletin/09/07/14; Michelle Collins, "Kenney's Political Interference Crippling Refugee Board: Former Chair" Embassy Magazine (22 July 2009), online: No One is Illegal http://noii-van.resist.ca/?p=1189\#more-1189.

8. Ibid.

9. Ibid.

10. Immigration and Refugee Protection Act, SC 2001, c 27, s 162(1) [IRPA].

11. Ibid, s 3(2)(c).

12. Ibid, s 3(2)(e).

13. 2001 SCC 52, [2001] 2 SCR 781 at para 24 [Ocean Port].

14. Singh $v$ Minister of Employment and Immigration, [1985] 1 SCR 177.

15. Ibid at paras 83,87 .

16. See, for instance, Benitez v Canada (Minister of Citizenship and Immigration), 2006 FC 461, [2007] 1 FCR 107 at para
47; Thamotharem $v$ Canada (Minister of Citizenship and Immigration), 2006 FC 16, [2006] 3 FCR 168 at para 59.

17. Suresh $v$ Canada (Minister of Citizenship and Immigration), 2002 SCC 1, [2002] 1 SCR 3 at para 118.

18. Ibid at para 5 .

19. Gerald Heckman \& Lorne Sossin, "How Do Canadian Administrative Law Protections Measure Up to International Human Rights Standards? The Case of Independence" (2005) 50 McGill LJ 193 at 245 (QL).

20. Kozak v Canada (Minister of Citizenship and Immigration), 2006 FCA 124, [2006] 4 FCR 377 at para 53 [Kozak].

21. Valente $v$ the Queen, [1985] 2 SCR 673 [Valente].

22. [1995] 1 SCR 3 at para 83.

23. IRPA, supra note 10 at 153(1)(a).

24. Canada, Office of the Auditor General, 2009 March Status Report of the Auditor-General (Ottawa: OAG, 2009) at 2.88 [OAG, 2009 Report].

25. IRPA, supra note 10 at $153(1)(\mathrm{c})$.

26. Canada, Office of the Auditor-General, 1997 December Report of the Auditor General (Ottawa: OAG, 1997) at 25.70 [OAG, 1997 Report].

27. Formoredetails, seee.g.CitizenshipandImmigrationCanada, News Release, "Minister Finley announces revised selection process for appointments to the IRB" (9 July 2007) online: http://www.cic.gc.ca/english/department/media/releases /2007/2007-07-09.asp; OAG, 2009 Report, supra note 24 at 2.84-2.88.

28. OAG, 1997 Report, supra note 26 at 25.78.

29. Canada, Office of the Auditor General, 2001 December Report of the Auditor General (Ottawa: OAG, 2001) at 12.75.

30. Ibid.

31. Canada, Immigration and Refugee Board, The Selection Process for Governor in Council Appointments to the Immigration and Refugee Board of Canada, online: Immigration and Refugee Board of Canada http://www.irb.gc.ca/eng/ brdcom/empl/memcom/Pages/process.aspx.

32. OAG 2009 Report, supra note 24 at 2.99, 2.100.

33. Ibid at 2.96 .

34. House of Commons, Standing Committee on Citizenship and Immigration, "Safeguarding Asylum-Sustaining Canada's Commitments to Refugees" in Report 15 (May 2007) at 22-23.

35. Ibid at 23.

36. Valente, supra note 21 at 31.

37. Katrina Miriam Wyman, "Appointments to Adjudicative Tribunals: Politics and Courts" (1999) 57 U T Fac L Rev 101 at 113 (QL).

38. [1996] 3 SCR 919 at para 67 [Régie].

39. 2003 SCC 36, [2003] SCR 884, at para 53 [Bell Canada].

40. Régie, supra note 38 at para 28.

41. Reference re Remuneration of Judges of the Provincial Court of Prince Edward Island, [1997] 3 SCR 3.

42. In Bell Canada, the appointment renewal was only valid until the completion of an ongoing hearing.

43. [1991] 2 SCR 114 at 144. 
44. Committee for Justice and Liberty v National Energy Board, [1978] 1 SCR 369, at 394.

45. Ibid at 395.

46. Collins, supra note 7.

47. Sara Blake, Administrative Law in Canada, 2nd ed (Toronto: Butterworths, 1997) at 87.

48. Heckman \& Sossin, supra note 19 at 258-59, note 295.

49. Wyman, supra note 37 at 109.

50. Heckman \& Sossin, supra note 19 at 257-58.

51. Susan Kneebone, "Is the Australian Refugee Review Tribunal "Institutionally" Biased?" in Francois Crepeau et al., eds, Forced Migration and Global Processes: A View from Forced Migration Studies (Oxford: Lexington Books, 2006) 237 at 238.

52. Kozak, supra note 20 at para 66.

53. See, for instance, Michel Comte, "Canada unveils law to curb illegal immigration" AFP (21 October 2010), online: Google Hosted News http://www.google.com/hostednews/ afp/article/ALeqM5i5PJUcumwtEScS_vP36fiktBrcZQ ?docId=CNG.66862e97ec6a36825c962fc93c1e1083.291.
54. Cervenakova $v$ Canada (Citizenship and Immigration), 2010 FC 1281; Zupko $v$ Canada (Citizenship and Immigration), 2010 FC 1319; Gabor v Canada (Citizenship and Immigration), 2010 FC 1162.

55. Ibid at para 33.

56. Cervenakova, supra note 54 at paras 52, 55.

57. Zupko, supra note 54 at para 20.

Jacqueline Bonisteel is completing a JD at the University of Ottawa's Faculty of Law and an MA in international affairs at Carleton University's Norman Paterson School of International Affairs (candidate-2011). 